\title{
6
}

\section{The Third Prerequisite: Shift the Focus of Imprisonment to the Goal of Rehabilitation and Restoration}

\section{Introduction}

International human rights law requires the goal of the prison system to be 'rehabilitation and social reformation'. The full wording of art 10(3) of the International Covenant on Civil and Political Rights (ICCPR) is, ' $[\mathrm{t}]$ he penitentiary system shall comprise treatment of prisoners the essential aim of which shall be their reformation and social rehabilitation' (emphasis added). ${ }^{1}$ This obligation poses three problems, all of which need to be addressed if Australia is to comply with this requirement.

First, international human rights law provides inadequate guidance as to how the goal of rehabilitation and social reformation is to be achieved in practice. In the absence of more detailed guidance from the United Nations Human Rights Committee (HR Committee), 'it is generally perceived that states have broad discretion in how they approach the Article 10(3) obligation'.

1 International Covenant on Civil and Political Rights, opened for signature 19 December 1966, 999 UNTS 171 (entered into force 23 March 1976) ('ICCPR').

2 Sarah Joseph and Melissa Castan, The International Covenant on Civil and Political Rights. Cases, Materials, and Commentary (Oxford University Press, $3^{\text {rd }}$ ed, 2013) 325; Sarah Joseph, Katie Mitchell and Linda Gyorki, Seeking Remedies for Torture Victims. A Handbook on the Individual Complaint Procedures of the UN Treaty Bodies (World Organisation Against Torture, 2006) 203. 
Three clauses in General Comment 21 (which is mainly about art 10(1) of the ICCPR) issued by the HR Committee refer to the obligations under art 10(3). These refer to 'assistance after release', the availability of 'teaching, education and re-education, vocational guidance and training and also concerning work programmes for prisoners' and contact with the 'outside world' while imprisoned. ${ }^{3}$ Naylor and Winford have concluded that this General Comment indicates that 'prison-based correctional rehabilitation is generally considered to consist of "programmes" offered to offenders. ${ }^{4}$

There have been very few individual communications to the HR Committee brought under art 10(3). The few from Australia usefully illustrate how communications shed little light on the challenges states parties to the ICCPR face with complying with art 10(3).

One communication where it was found that Australia was violating art 10(3) was that involving $\mathrm{Mr}$ Brough, the circumstances of which were discussed in Chapter 2. The HR Committee's findings provide little guidance about how broader compliance is to be achieved across the entire prison system. ${ }^{5}$ In another communication from Australia, from Mr Jensen in Western Australia (WA), Mr Jensen claimed:

while in prison he has followed intensive therapy and that the psychological reports show that he is unlikely to re-offend. The author argues that further imprisonment, after he was ready to be rehabilitated and reintegrated in society, for offences that happened ten years ago, is detrimental to his rehabilitation and has led to heavy emotional and psychological stress. He thus claims a violation of article 10, paragraph 3, of the Covenant. ${ }^{6}$

3 United Nations Human Rights Committee, CCPR General Comment No. 21: Article 10 (Humane Treatment of Persons Deprived of Their Liberty) (10 April 1992) [10]-[12].

4 Bronwyn Naylor and Stan Winford, 'Implementing the OPCAT Through Prison Monitoring: The Relevance of Rehabilitation' (2019) 25(1) Australian Journal of Human Rights 113, 116.

5 Human Rights Committee, Views: Communication No 1184/2003, UN Doc CCPR/C/86/D/ 1184/2003 (17 March 2006) ('Brough v Australia') [9.4]. For another communication where a violation of art 10(3) has been upheld see Human Rights Committee, Views: Communication No 878/99, UN Doc CCPR/C/78/D/878/1999 (15 July 2003) ('Kang v Republic of Korea'). Similarly, the Committee on the Rights of Persons with Disabilities guidance on the right to 'habitation and rehabilitation' contained in art 26 of the Convention of the Rights of Persons with Disabilities in the context of Australian prisons is vague. The Committee's views in response to two recent communications concerning Australia found that the authors of the communication and the state party (Australia) provided different information about the services provided and that 'the information provided does not enable it to conclude' that art 26 had been violated: Committee on the Rights of Persons with Disabilities, Views: Communication No 17/2013, UN Doc CRPD/C/22/D/17/2013 (30 August 2019) ('Leo v Australia') [8.12]; Committee on the Rights of Persons with Disabilities, Views: Communication No 18/2013, UN Doc CRPD/C/22/D/ 18/2013 (30 August 2019) ('Doolan v Australia') [8.10].

6 Human Rights Committee, Views: Communication No 762/1997, UN Doc CCPR/C/71/D/ 762/1997 (22 March 2001) ('Jensen v Australia') [3.5]. 
The HR Committee found that Mr Jensen had failed to substantiate his claims and held it was inadmissible. ${ }^{7}$

Second, the Australian criminal justice system seeks to achieve many goals other than rehabilitation, such as deterrence and retribution, in addition to rehabilitation. In other words, rehabilitation is one goal within a matrix. Moreover, as noted in Chapter 5, the Australian Capital Territory (ACT), Victoria and Queensland have not incorporated art 10(3) of the ICCPR into their human rights legislation. Therefore, the article does not form part of domestic law even in the three jurisdictions that afford imprisoned people domestic human rights protections.

Third, the ICCPR was drafted and adopted in 1966 during a time when 'penal welfarism' was the dominant paradigm. This era was followed by a loss of faith in rehabilitation among criminologists, known as the 'decline of the rehabilitative ideal'. ${ }^{8}$ Due to these shifts, Joseph and Castan speculate that "[i]t is possible that the "rehabilitation" aspect of article 10(3) has been treated by States Parties as an anachronism? ${ }^{\text {? }}$

Despite these problems, Australia still has an obligation to comply with art 10(3) of the ICCPR. Consequently, there is a need for practical strategies for achieving this goal at the level of daily prison operations. A way forward may be to develop a rights-based approach to rehabilitation as restoration in Australian prisons. A discussion of the advantages and barriers to such an approach being implemented in Australia concludes this chapter. ${ }^{10}$

7 Ibid [9.4]. The claim under art 10(3) in relation to imprisoned people on death row was also held to be inadmissible in Human Rights Committee, Views: Communication No 748/1997, UN Doc CCPR/C/67/D/748/1997 (3 June 1998) ('McTaggart v Jamaica').

8 These developments are outlined in more detail in Anita Mackay, 'The Road to the ACT's First Prison (the Alexander Maconochie Centre) was Paved with Rehabilitative Intentions' (2012) 11(1) Canberra Law Review 33, 48-52.

9 Joseph and Castan, above n 2, 325. By point of comparison, the European Court of Human Rights imposed a positive obligation on European countries to achieve rehabilitation in 2016 in the decision of Murray $v$ The Netherlands [2016] ECHR 10511/10. For a discussion see Sonja Meijer, 'Rehabilitation as a Positive Obligation' (2017) 25 European Journal of Crime, Criminal Law and Criminal Justice 145.

10 The scope of this book is, as much as possible, confined to what occurs within prisons, as opposed to how people end up in prison and what occurs after their release. It is not entirely possible to exclude a discussion about what occurs once a person returns to the community when dealing with the requirement of prisons to rehabilitate. However, this chapter in no way attempts to comprehensively deal with the broad range of criminological research and debates about re-entry/reintegration/desistance/ resettlement and other similar concepts, nor with the measurement of recidivism. An explanation of the relationship between the relevant concepts is provided by Shadd Maruna, Russ Immarigeon and Thomas LeBel, 'Ex-Offender Reintegration: Theory and Practice' in Shadd Maruna and Russ Immarigeon (eds), After Crime and Punishment. Pathways to Offender Reintegration (Willan Publishing, 2004). 


\section{Rehabilitation in the Matrix of the Goals of Australian Prisons}

Because of the federal system, there is neither horizontal nor vertical uniformity across Australian prisons. Goals are not set at the national level because the responsibility for imprisonment lies with the states and territories. States and territories specify different goals in their legislation. Nor is there a single type of legislation in which to locate the goals of the prison system. Information pertaining to goals can be found in both corrections legislation and sentencing legislation.

Sentencing legislation and corrections legislation have different aims. Sentencing legislation concerns the imposition of an appropriate sanction on someone who has committed a criminal offence by reference to various goals (detailed below). Imprisonment is one such sanction, and it is usually specified to be the sanction of 'last resort'. Corrections legislation is narrower in focus. It concerns the administration of prisons and community corrections, and is mostly administrative.

A detailed analysis of both types of legislation across jurisdictions reveals that there are many goals of the Australian prison system, including deterrence and retribution. Rehabilitation is sometimes one of these goals, but the situation is by no means uniform.

\section{Corrections Legislation}

In three out of eight Australian jurisdictions, corrections legislation identifies rehabilitation as one explicit object of the corrections system. These are the ACT, New South Wales (NSW) and Queensland. ${ }^{11}$ Some other jurisdictions do not contain objects provisions in their corrections legislation (WA, Northern Territory, South Australia ${ }^{12}$ ), and the other jurisdictions (Victoria and Tasmania ${ }^{13}$ ) contain objects provisions that do not feature rehabilitation.

11 Corrections Management Act 2007 (ACT) s 7(d); Crimes (Administration of Sentences) Act 1999 (NSW) s 1(d); Corrective Services Act 2006 (Qld) s 3(1).

12 Prisons Act 1981 (WA); Correctional Services Act (NT); Correctional Services Act 1982 (SA).

13 Corrections Act 1986 (Vic) s 1; Corrections Act 1997 (Tas) s 4. 
In the three jurisdictions that include rehabilitation as a goal, none prioritise it above other goals. Further, in all cases, public safety and the maintenance of security in prisons are the priorities. For example, s 3(1) of the Corrective Services Act 2006 (Qld) provides that ' $\mathrm{t}$ ] he purpose of corrective services is community safety and crime prevention through the humane containment, supervision and rehabilitation of offenders' ${ }^{14}$

As outlined in Chapter 5, security is used to justify limitations on human rights contained in human rights legislation. Rehabilitation is given the lowest priority in the three jurisdictions that include it as a goal within corrections legislation. It is more often the case than not that, in practice, security considerations outweigh it.

\section{Sentencing Legislation}

Sentencing legislation also incorporates several goals. An example from NSW is extracted below. While in theory sentencing goals are designed to be equal, as Freiberg observes, '[a]ll these purposes cannot, in logic, coexist'. ${ }^{15}$ Therefore, it usually falls to the sentencing judge to strike a balance between the goals when deciding whether to impose a prison sentence. Imprisonment is the harshest penalty available to sentencing judges and is deemed by legislation around the country to be appropriate only after other options have been ruled out - it is intended to be a 'last resort'. ${ }^{16}$ As discussed in Chapters 1 and 4, the growth of the prison population, over-reliance on prison as a sanction and consequent overcrowding of Australian prisons reveals that prison as a 'last resort' is far from the reality.

Rehabilitation as a goal features in the sentencing legislation of six out of eight Australian jurisdictions-all except WA and Tasmania. ${ }^{17}$ Therefore, in the absence of reference to rehabilitation in corrections legislation, WA and Tasmania have no reference at all to rehabilitation in either corrections or sentencing legislation.

14 See also Crimes (Administration of Sentences) Act 1999 (NSW) s 2A; Correctional Management Act 2007 (ACT) s 7.

15 Arie Freiberg, Fox \& Freiberg's Sentencing: State and Federal Law in Victoria (Lawbook Co, $3^{\text {rd }}$ ed, 2014) 235 .

16 See, eg, Crimes (Sentencing) Act 2005 (ACT) s 10(2); Penalties and Sentences Act 1992 (Qld) s 9(2)(a); Sentencing Act 1997 (Tas) s 12; Crimes (Sentencing Procedure) Act 1999 (NSW) s 5(1). This also reflects the common law position: ibid 729. The 'matters that the courts have said to point to imprisonment' are outlined by ibid 731 .

17 Lesley Hardcastle, Terry Bartholomew and Joe Graffam, 'Legislative and Community Support for Offender Reintegration in Victoria' (2011) 16(1) Deakin Law Review 111, 114. 
In the six jurisdictions that include rehabilitation, the goals against which rehabilitation must be balanced are numerous. An example of the goals that are to be balanced when a person is being sentenced can be found in s 3A of the NSW Crimes (Sentencing Procedure) Act 1999, as follows:

The purposes for which a court may impose a sentence on an offender are as follows:

(a) to ensure that the offender is adequately punished for the offence,

(b) to prevent crime by deterring the offender and other persons from committing similar offences,

(c) to protect the community from the offender,

(d) to promote the rehabilitation of the offender,

(e) to make the offender accountable for his or her actions,

(f) to denounce the conduct of the offender,

(g) to recognise the harm done to the victim of the crime and the community. ${ }^{18}$

These goals are diverse. Some, such as deterring the offender from committing further crimes and rehabilitating them, are forward looking. ${ }^{19}$ Others, such as those concerned with retribution/punishment and holding the offender accountable, and those considering the harm inflicted upon the victim and the community, look back at the criminal action..$^{20}$ Moreover, some are targeted at the individual offender (their punishment, rehabilitation and accountability), while others focus on the interests of the community (the need for protection and deterring other people from committing similar offences).

Many of these goals have origins in broader theories about the organisation of society. ${ }^{21}$ For example, the principle of general deterrence (that is, that imprisoning one person will deter others from committing the same crime) is based on Bentham's theory of utilitarianism, being the greatest good for the greatest number. ${ }^{22}$ As Cavadino and Dignan succinctly explain:

18 Emphasis added. Other state and territory legislation is similar. See, eg, Crimes (Sentencing) Act 2005 (ACT) s 7; Sentencing Act 1991 (Vic) s 5; Penalties and Sentences Act 1992 (Qld) s 9.

19 Simon Bronitt and Bernadette McSherry, Principles of Criminal Law (Lawbook Co, $3^{\text {rd }}$ ed, 2010) 21.

20 Ibid 19.

21 Although the way in which the goals are translated into practice in the current system does not necessarily adhere entirely to these theories.

22 See, eg, Jeremy Bentham, A Fragment on Government (Clarendon Press, 1891); Jeremy Bentham, Introduction to the Principles of Morals and Legislation (Clarendon Press, 1789). Another example is the goal of denunciation stemming from the work of Durkheim: Michael Cavadino and James Dignan, The Penal System. An Introduction (SAGE, 2007) 47. 
If punishment does indeed reduce the future incidence of crime, then the pain and unhappiness caused to the offender may be outweighed by the unpleasantness to other people in the future which is prevented - thus making punishment morally right from a utilitarian point of view. ${ }^{23}$

Rehabilitation is clearly not the prime statutory goal of sentencing in Australia. Consequently, the more serious the offence, the less likely it is that priority will be given to rehabilitation when sentencing decisions are being made. As Freiberg argues, '[i]t will become part of the instinctive synthesis and will be subjugated to other sentencing principles if the offence is particularly serious. ${ }^{24}$

\section{Legal Position of Rehabilitation as a Goal}

It is clear from the above that rehabilitation as a goal of imprisonment is not given the primacy required by art 10(3) of the ICCPR. In two jurisdictions (WA and Tasmania), it is noticeable only for its absence in legislation. In the jurisdictions that do include it, the legislation has been described as giving it mere 'lip service'. ${ }^{25}$ Competing goals, such as maintaining security within prisons or general deterrence, are higher priorities. Even if rehabilitation features as a rhetorical goal, this does not necessarily translate into reality. ${ }^{26}$

It seems unlikely that this situation will change in the near future. For example, the ACT, Victoria and Queensland have not incorporated art 10(3) into their human rights legislation. The Explanatory Statement for the Human Rights Bill 2003 (ACT) justifies the omission of certain articles of the ICCPR as follows: '[i]n some instances a right has been omitted because it is not appropriate to the ACT as a territory under the authority of the Commonwealth'. However, given the ACT Government

23 Cavadino and Dignan, above n 22, 37.

24 Freiberg, above n 15, 258.

25 Rick Sarre, 'Beyond "What Works?" A 25-Year Jubilee Retrospective of Robert Martinson's Famous Article' (2001) 34(1) Australian and New Zealand Journal of Criminology 38, 42. See also Karen Heseltine, Andrew Day and Rick Sarre, Prison-Based Correctional Offender Rehabilitation Programs: The 2009 National Picture in Australia (Australian Institute of Criminology Reports Research and Public Policy Series 112, 2011) 12. Naylor and Winford have observed that the lack of legislative guidance' contributes to the 'ill-defined' nature of rehabilitation in Australia: Naylor and Winford, above $\mathrm{n} 4,115$.

26 This argument has been made in relation to Queensland: Tamara Walsh, 'Is Corrections Correcting? An Examination of Prisoner Rehabilitation Policy and Practice in Queensland' (2006) 39(1) Australian and New Zealand Journal of Criminology 109, 111. 
has responsibility for corrections in the territory under s 37 and sch 4 of the Australian Capital Territory (Self-Government) Act 1988 (Cth), this does not provide an adequate explanation as to why art 10(3) has been omitted from the Human Rights Act 2004 (ACT).

In the Victorian Government's submission to a review of the Charter of Human Rights and Responsibilities Act 2006 (Vic) by the Victorian Scrutiny of Acts and Regulations Committee, it was stated that the reason for the omission of art 10(3) in Victoria was because 'the prison system may have other aims and that this was a matter for public debate'. ${ }^{27}$

In Chapter 5, it was argued that states and territories need to undertake legislative reform to achieve the second prerequisite (alignment of domestic legislation with Australia's international human rights law obligations). This is particularly the case now that Australia has ratified the Optional Protocol to the Convention against Torture and Other Cruel, Inhuman or Degrading Treatment or Punishment (OPCAT) ${ }^{28}$ It was argued that states and territories other than the ACT, Victoria and Queensland might consider introducing a specific Human Rights Act. If they did so, this could incorporate art 10(3) and the ACT, Victoria and Queensland could also make this change. Alternatively, or additionally, corrections legislation could be amended to protect human rights and this could include adding rehabilitation as an aim in the jurisdictions that currently do not include it.

In the meantime, however, having concluded that rehabilitation is either a non-existent or non-prominent goal in corrections, sentencing and human rights legislation, it is necessary to explore non-legislative mechanisms by which rehabilitation might still be given appropriate importance.

27 Victorian Government, Submission 324 to Scrutiny of Acts and Regulations Committee, Review of the Charter of Human Rights and Responsibilities Act 2006, 2011, 70.

28 Optional Protocol to the Convention against Torture, adopted 18 December 1992, UN Doc A/RES/ 57/199 (entered into force 22 June 2006) ('OPCAT'). 


\section{Rights-Based Model of Rehabilitation and Practical Strategies for Implementation}

There is more than one way of approaching the issue of rehabilitation. A 'rights-based model', with particular emphasis on the conceptualisation of rehabilitation as 'restoration', is one with much to recommend it. From it can be formulated a strategy to move beyond the fact that rehabilitation is not given precedence in Australian legislation, towards compliance with art 10 (3) at a practical level. Such a strategy also serves to give meaning to art 10(3) at the level of day-to-day prison operations and go some way towards overcoming the lack of guidance provided by the HR Committee.

\section{Rights-Based Model of Rehabilitation}

Critique has been levelled at the treatment-based model of rehabilitation. This is a model that considers individuals as needing to be 'treated' for the benefit of society-to make society safer. ${ }^{29} \mathrm{~A}$ problem with this conceptualisation is that it denies the role of social disadvantage in leading people to commit crime. ${ }^{30}$ An alternative approach was developed in response to this inadequacy. According to Raynor and Robinson, it 'rests on a version of social contract theory: the moral legitimacy of the State's demand that people refrain from offending is maintained if the State fulfils its duty to ensure people's basic needs are met'. ${ }^{31}$ In addition to imposing a responsibility on the state, this conceptualisation views people who have committed an offence as capable of learning new skills, rather than needing to be 'treated'. 32

This alternative approach is the rights-based model of rehabilitation. It contains four key components. The first is that people have a 'right' to rehabilitation, particularly when they are incarcerated. ${ }^{33}$ Rotman defines the right as one of the offenders to certain minimum services from the correctional authorities. The purpose of such a right is to offer

29 Peter Raynor and Gwen Robinson, Rehabilitation, Crime and Justice (Palgrave Macmillan, 2005) $24-5$.

30 Ibid 25.

31 Ibid 27. See also Sam Lewis, 'Rehabilitation: Headline or Footnote in the New Penal Policy?' (2005) 52(2) Probation Journal 119, 124-5.

32 Peter Raynor and Gwen Robinson, 'Why Help Offenders? Arguments for Rehabilitation as a Penal Strategy' (2009) 1(1) European Journal of Probation 3, 14.

33 Lewis, above n 31, 124. 
each offender an opportunity to reintegrate into society as a useful human being' ${ }^{34}$ Rotman makes clear that this imposes both positive and negative duties on the state. The positive ones include the duty of correctional authorities to offer education and training. The negative duties include ensuring that people are not being subjected to the physical and mental harm that flows from incarceration, because this makes it difficult for people to adapt back into society. ${ }^{35}$

These negative aspects lead to the second component of the rights-based model of rehabilitation-that prison should remain a 'last resort'. ${ }^{36}$ While not specified by Rotman in precisely these terms, his argument alludes to reasons why there should be reduced reliance on imprisonment, including the need to avoid the 'pains of imprisonment' and the risks of 'prisonisation'. ${ }^{37}$

Third, sentencing should be disconnected from considerations about rehabilitation and focus instead on culpability for the crime committed. ${ }^{38}$ This is to overcome one of the critiques of rehabilitation that arose during the decline of the rehabilitative ideal — that sentences based on the (indeterminate) time it may take to rehabilitate a person were perceived to be bringing the justice system into disrepute. Overly harsh sentences also infringe the right to rehabilitation. ${ }^{39}$

Finally, rehabilitation should be voluntary, rather than coerced. ${ }^{40}$ This is a complex issue, especially in the context of court-ordered rehabilitation and incarceration. However, at the very least, people 'should have some choice about how to utilize rehabilitative opportunities in order to respect their right to autonomy and self-determination'. ${ }^{41}$

34 Edgardo Rotman, Beyond Punishment. A New View on the Rehabilitation of Criminal Offenders (Greenwood Press, 1990) 6.

35 Ibid.

36 Lewis, above $\mathrm{n} 31$; ibid 15.

37 Rotman, above n 34, 143-4. The 'pains of imprisonment' were discussed in Chapter 1. 'Prisonisation' refers to the process whereby people become conditioned by prison rules, procedures and routines, making them less likely to be able to function as law-abiding citizens upon their return to the community. The longer people spend in prison, the more likely they are to be negatively affected by that environment. This is also known as 'institutionalisation'.

38 Lewis, above $\mathrm{n} 31,124$.

39 Ibid.

40 Ibid.

41 Ibid 125 (noting that 'how this might be achieved in practice should be the subject of lengthy and earnest debate'). 
This rights-based conceptualisation of rehabilitation accords with international human rights law-particularly, by aiming to ensure that prison remains a sanction of last resort. This aligns with the first prerequisite for human rights compliance in this book. This conceptualisation also attempts to overcome the concerns that led to the decline of the rehabilitative ideal.

\section{Implementing the Rights-Based Model}

There are two main approaches to implementing the rights-based model of rehabilitation. These are the Good Lives Model of Offender Rehabilitation (GLM) and the restorative justice approach to rehabilitation. A short summary of both is provided here, though a preliminary comment is appropriate.

First, and most importantly, the GLM is a framework for therapeutic intervention by clinical practitioners. In contrast, restorative justice may be used as an overarching philosophy for prison operation such that all prison staff are required to assist imprisoned people with their preparation for returning to the community. The restorative justice framework, which involves all prison staff, is preferable in Australian prisons where there is clear demarcation between custodial staff on the one hand, and professional staff who would be implementing the GLM on the other. It is also preferable given that art 10(3) relates to the 'essential aim' of imprisonment, which extends beyond the aim of therapeutic interventions.

\section{Good Lives Model of Offender Rehabilitation}

The GLM was first proposed by Ward and Stewart in 2003 and developed to complement the Risk-Need-Responsivity model (RNR model). ${ }^{42}$ The GLM is described as a 'rehabilitation framework', within which various specific treatment methods (such as cognitive behavioural therapy) can be used by practitioners. ${ }^{43}$ Fortune, Ward and Willis have described the GLM as:

42 Clare-Ann Fortune, Tony Ward and Gwenda Willis, 'The Rehabilitation of Offenders: Reducing Risk and Promoting Better Lives' (2012) 19(5) Psychiatry, Psychology and Law 646, 653; Chi Meng Chu, Tony Ward and Gwenda Willis, 'Practising the Good Lives Model (GLM)' in Ioan Durnescu and Fergus McNeill, Understanding Penal Practice (Taylor and Francis, 2013) 206.

43 Fortune, Ward and Willis, above n 42, 656. 
a strength-based rehabilitation theory as it is responsive to offenders' particular interests, abilities, and aspirations and directs practitioners to develop intervention plans which assist offenders in acquiring the capabilities and accessing the relevant internal and external resources to achieve goals which are personally meaningful. ${ }^{44}$

The individual agency of individuals is the first assumption on which the GLM is based, because it is grounded in the concept of human dignity. ${ }^{45}$ Another assumption on which the GLM is based is that 'offenders, like all individuals, are goal directed and attempt to seek primary human goods' ${ }^{46}$ There are 11 of these 'primary goods', including knowledge, life (including good health) and relatedness. ${ }^{47}$ Therapeutic intervention under the GLM aims to assist individuals to access these goods without engaging in illegal behaviour. ${ }^{48}$

Because of the emphasis on human dignity and helping people learn, the GLM is arguably a useful way to achieve a rights-based approach to rehabilitation. However, for the reasons outlined above, rehabilitation as restoration is a better suited, more comprehensive way of achieving the third prerequisite in Australia.

\section{Restorative Justice Approach}

\section{Defining Restorative Justice}

It is difficult to define restorative justice comprehensively because it has become an 'umbrella term' used to refer to a wide range of strategies to address both criminal and non-criminal behaviour (eg, anti-bullying programs in schools) ${ }^{49}$ However, a commonly adopted definition, espoused by Marshall, is that ' $[\mathrm{r}]$ estorative justice is a process whereby all the parties with a stake in a particular offence come together to resolve collectively how to deal with the aftermath of the offence and its implications for the

\footnotetext{
44 Ibid 654.

45 Ibid.

46 Chu, Ward and Willis, above $\mathrm{n}$ 42, 207.

47 Ibid 207.

48 Fortune, Ward and Willis, above $\mathrm{n} 42,10$. This is done in a five phase process, outlined by Chu, Ward and Willis, above n 42, 209-10.

49 John Pratt, 'Beyond Evangelical Criminology: The Meaning and Significance of Restorative Justice' in Ivo Aertsen, Tom Daems and Luc Robert (eds), Institutionalizing Restorative Justice (Willan Publishing, 2006) 44.
} 
future'. ${ }^{50}$ When Marshall refers to those with 'a stake' in the offence, this includes the victim and the community, but it also necessarily includes the person who committed the offence. Restorative justice shifts the emphasis from the state vis-à-vis the person who committed the offence, to that person vis-à-vis the victim and the community.

At the broad level, within a restorative justice framework, the person who committed the offence is required to acknowledge the harm they have caused to the victim and the community and, 'as much as possible', make amends for that harm. ${ }^{51}$ The community then has a responsibility to support the person's reintegration. ${ }^{52}$

\section{Relationship Between Restorative Justice, Rights and Rehabilitation}

Connections between restorative justice and rehabilitation are not immediately obvious and there are commentators who argue they should be kept separate. ${ }^{53}$ This may be because the two have often been juxtaposed, ${ }^{54}$ with restorative justice presented as an alternative goal of criminal justice - that is, an alternative to rehabilitation, retribution, deterrence and other goals. ${ }^{55}$ It may also be because rehabilitation focuses on the person who committed the offence, whereas restorative justice has been presented as extending the focus to victims and other stakeholders. ${ }^{56}$ The latter is not necessarily an accurate portrayal of restorative justice, especially in light of recent literature exploring the capacity of restorative justice to promote desistance from criminal offending. ${ }^{57}$

However, it is difficult to sustain a strict demarcation between restorative justice and rehabilitation. The origin of the word 'rehabilitation' tends to support an overlap between 'rehabilitation' and 'restoration'. Mathieson explains its etymology as follows:

50 Cited by John Braithwaite, Restorative Justice and Responsive Regulation (Oxford University Press, 2002) 11 .

51 Howard Zehr and Harry Mika, 'Fundamental Concepts of Restorative Justice' (1997) 1(1) Contemporary Justice Review 47, 48.

52 Ibid 49.

53 Tony Ward and Robyn Langlands, 'Repairing the Rupture: Restorative Justice and the Rehabilitation of Offenders' (2009) 14 Aggression and Violent Behavior 205.

54 Raynor and Robinson, above n 29, 136.

55 Braithwaite cited by ibid 136.

56 Raynor and Robinson, above n 29, 136.

57 Ibid 137. An example of this is Tony Ward, Kathryn Fox and Melissa Garber, 'Restorative Justice, Offender Rehabilitation and Desistance' (2014) 2(1) Restorative Justice: An International Journal 24. 
'Rehabilitation' is a combined French and Latin word, coming from the French re, which means 'return' or 'repetition', and the Latin habilis, which means 'competent'. Originally, the word thus denoted 'return to competence'. Today the word denotes in a broad sense the process of bringing something back to functioning order. ${ }^{58}$

Mathieson goes on to consider how the term is applied in the prison context, which also connects the term to 'restoration': 'What about the prisoner? The shades of meaning mentioned are also relevant to him or her. The prisoner is to be restored to his or her old form, notably the form before the crime'. ${ }^{59}$

There are several commentators who argue that restorative justice is connected to rehabilitation. Zedner, for instance, argues that restorative justice is being 'seen as an attempt to revive rehabilitation for a new political era' ${ }^{60}$ Raynor and Robinson have argued that restorative justice is a method of rights-based rehabilitation because of 'the fact that offenders involved in restorative procedures are meant to learn a social lesson which will influence their future behaviour' ${ }^{61}$ This aligns with the learning model of rehabilitation, as opposed to the largely discredited treatment model. Further, Dhami et al have suggested that 'RJ [restorative justice] and imprisonment are seemingly compatible when the goal of both is to rehabilitate'. ${ }^{62}$ Significantly for this prerequisite, Wallace and Wylie argue that restorative justice is useful in achieving compliance with art 10(3) of the ICCPR. ${ }^{63}$

58 Thomas Mathieson, Prison on Trial (Waterside Press, $3^{\text {rd }}$ ed, 2006) 27 (emphasis in original).

59 Ibid.

60 Lucia Zedner, 'Dangers and Dystopias in Penal Theory' (2002) 22(2) Oxford Journal of Legal Studies 341, 356.

61 Raynor and Robinson, above n 32, 13. See also Raynor and Robinson referring to the work of Bazemore: Raynor and Robinson, above n 29, 138.

62 Mandeep Dhami, Greg Mantle and Darrell Fox, 'Restorative Justice in Prisons' (2009) 12(4) Contemporary Justice Review 433, 435.

63 Rebecca Wallace and Karen Wylie, 'Changing on the Inside: Restorative Justice in Prisons: A Literature Review’ (2013) 19 Journal of Bahamian Studies 57, 66. 


\section{Rehabilitation and Restoration in Australia}

What are the implications of these theoretical and practical developments for Australia? The above discussion suggests that restorative justice as a rights-based approach to rehabilitation offers significant potential to overcome some of the problems with rehabilitation identified in the criminological literature. Therefore, it could be very helpful as a strategy to assist Australia in meeting its obligations to comply with art 10(3) of the ICCPR. More specifically, restorative prisons offer practical strategies to overcome the lack of focus on rehabilitation in Australian corrections and sentencing legislation-a necessary first step for compliance. Therefore, there are a number of good reasons for considering the adoption of restorative justice in Australian prisons. There are also many barriers that would need to be overcome.

\section{Arguments for the Restorative Approach to Rehabilitation}

Three reasons may be used to support the restorative approach to rehabilitation for the purposes of improving compliance with art 10(3) of the ICCPR in Australian prisons.

\section{Established Nature of Restorative Justice}

The main advantage of this approach is that there are already wellestablished restorative justice processes in operation in Australia and a consequent level of expertise. Australia and New Zealand are considered world leaders in the use of restorative justice conferencing, especially for juveniles. ${ }^{64}$ Conferencing began in New Zealand in 1989 and the New Zealand model has been adopted by a number of Australian jurisdictions. South Australia was the first state to introduce legislation to implement conferencing, and every jurisdiction uses conferencing for juveniles ${ }^{65}$ (with some authors arguing it has been institutionalised and that this is

64 Gabrielle Maxwell and Hennessey Hayes, 'Section F Pacific' of 'Regional Reviews' in Gerry Johnstone and Daniel Van Ness (eds), Handbook of Restorative Justice (Willan Publishing, 2003) 524; Hilde Tubex and Roger Houchin, 'Opportunities for Restorative Justice in the Contemporary Penal Climate' (2009) 11(2) Journal of Police Studies 173, 174.

65 Ibid 522, 524-5; Freiberg, above n 15, 266. 
problematic $\left.{ }^{66}\right)$. There are also restorative justice-based problem-solving courts, such as drug courts and Indigenous sentencing courts. ${ }^{67}$ Naylor argues that the latter are 'the closest in Australia to offering a "rehabilitative ritual"'. ${ }^{68}$ Restorative justice was the model used for a major taskforce established to respond to sexual offending and abuse in the defence forces (the Defence Abuse Response Taskforce). ${ }^{69}$

Although Australia has not adopted restorative justice as the overarching philosophy in prisons, there are nevertheless some restorative justice programs operating in Australian prisons. An example is the 'Sycamore Tree' program. ${ }^{70}$ Goulding et al argue that this program, operating in the Acacia prison in WA, includes one of the elements of restorative prisons'establishing an awareness of the impact of crime on victims through direct mediation'. ${ }^{71}$ These initiatives constitute a baseline from which it would be possible to move more broadly towards what may be termed 'restorative prisons'. ${ }^{72}$

\section{Broad Appeal to Victims and the Community}

Restorative justice-based approaches may appeal to the community because of their emphasis on making amends to the victims of crime, and also because the community work done by imprisoned people may improve community perceptions of incarcerated people. In relation

66 See Masahiro Suzuki and William Wood, 'Co-Option, Coercion and Compromise: Challenges of Restorative Justice in Victoria, Australia' (2017) 20(2) Contemporary Justice Review 274.

67 Arie Freiberg et al, Drug and Specialist Courts Review (Department of Justice and AttorneyGeneral, Queensland, 2016); Elena Marchetti, 'Indigenous Sentencing Courts in Australia' in Antje Deckert and Rick Sarre (eds), The Palgrave Handbook of Australian and New Zealand Criminology, Crime and Justice (Palgrave, 2017).

68 Bronwyn Naylor, 'Criminal Records and Rehabilitation in Australia' (2011) 3(1) European Journal of Probation 79, 93.

69 See further Alikki Vernon, 'The Ethics of Appropriate Justice Approaches: Lessons From a Restorative Response to Institutional Abuse' (2017) 35(1) Law in Context 139.

70 Dot Goulding, Guy Hall and Brian Steels, 'Restorative Prisons: Towards Radical Prison Reform' (2008) 20(2) Current Issues in Criminal Justice 231, 236, 239-40. The authors note that it would be preferable to have a secular program because the Sycamore Tree is a Christian faith-based program: ibid 239. More recently, the program has been redesigned in a way that has 'minimised' (but not 'excluded') the faith-based elements: see Jane Anderson, 'Introducing and Theorising an In-Prison Restorative Justice Programme: the Second-Generation Sycamore Tree Project' (2018) 1(2) International Journal of Restorative Justice 210, 214.

71 Goulding, Hall and Steels, above n 70, 240.

72 From 2000-04, the International Centre for Prison Studies had a project with the aim of considering 'the extent to which restorative principles could be used in the prison setting as a means of assisting prisoners to resettle into their communities after release'. Further information and research findings may be found at Restorative Prison Project <https://www.prisonstudies.org/resources/ restorative-prison-project- $0>$. 
to victims, it has been argued that 'the process attempts to restore the emotional (and sometimes financial) losses of the victim(s), as well as to redevelop their sense of security'. ${ }^{73}$ This emphasis given to the victim contrasts with traditional criminal justice processes, such as court hearings, that are essentially a matter between the state and the person who committed the offence. This often leaves the victim feeling sidelined. ${ }^{74}$ Members of the community can see that imprisoned people are making a contribution to society. This may go some way towards counteracting negative perceptions of people in prisons.

\section{Barriers to the Restorative Approach to Rehabilitation}

There are at least five barriers to compliance with art 10(3) of the ICCPR based on the restorative approach to rehabilitation.

\section{The Lack of a Legislative Mandate for Rehabilitation and Restoration}

As outlined earlier in this chapter (under 'Rehabilitation in the Matrix of the Goals of Australian Prisons'), rehabilitation is only one goal among many referred to in Australian sentencing and corrections legislation, and even then, not in all jurisdictions. Restoration is generally not referred to, with the general position summarised by Freiberg as: 'there is little formal recognition in sentencing statutes of the growing importance of other forms of reparation or restoration such as restorative justice' ${ }^{75}$

There are some references made to restoration as one of the many goals to be balanced when a sentence is being imposed. For example, $s$ 7(1)(g) of the Crimes (Sentencing) Act 2005 (ACT) stipulates that one purpose of sentencing be 'to recognise the harm done to the victim of the crime and the community. ${ }^{76}$ In Chapter 5 , it was argued that human rights legislation at the national level or in all states and territories is required to achieve human rights compliance in prisons (the second prerequisite). Similarly, it will be difficult for a restorative justice-based approach to

73 The Quaker Council for European Affairs, The Social Reintegration of Ex-Prisoners in Council of Europe Member States (Quaker Council for European Affairs, 2011) 108.

74 See further Jo-Anne Wemmers, 'Where Do They Belong? Giving Victims a Place in the Criminal Justice Process' (2009) 20 Criminal Law Forum 395.

75 Freiberg, above n 15, 266.

76 Note that this is similar to s $3 \mathrm{~A}(\mathrm{~g})$ of the Crimes (Sentencing Procedure) Act 1999 (NSW), cited in above $\mathrm{n} 16$. 
be implemented in Australian prisons in the absence of prioritisation of this goal in human rights, sentencing and corrections legislation in all jurisdictions (that is, in the absence of parliamentary endorsement).

\section{Overcrowding and Lack of Resources Allocated to Rehabilitation in Australian Prisons}

Overcrowding presents a significant challenge to achieving rehabilitation, as it does to achieving many of the other prerequisites proposed in this book. This is because resources are not necessarily increased as the prison population rises and restorative justice processes are resource intensive (eg, they require the specialist mediators to be engaged). Further, overcrowding often results in greater use of 'lock downs', such that people cannot attend the programs that are already in place. This development must be considered in the light of current practice that results in imprisoned people already spending an average of 15 hours per day in their cells even before 'lock downs' are taken into account. ${ }^{77}$ It significantly undermines the 'restorative prison' if people spend long hours in their cells and are therefore unable to attend mediation, work and courses. They also have their autonomy overridden in a security-focused environment.

\section{Imprisonment of People a Long Distance Away From Their Community of Origin}

Restorative prison processes rely on imprisoned people having mediation conferences with their victim/s (when appropriate), doing work for the community in which the crime was committed and building trusting relationships with that community. In Australia, particularly in geographically large jurisdictions such as WA and Queensland, people may be imprisoned many hundreds of kilometres away from the victim/s and that community. This makes the logistics of restorative prisons quite challenging.

\section{The Questionable Connection Imprisoned People may have had with the Community Prior to Their Incarceration}

Restorative prisons presume a re-establishment of connection with the community. This is problematic when the prison population is made up of predominantly marginalised individuals (as detailed in Chapter 1) who

77 Based on the national average of nine hours per day spent out of cells in secure prisons: Steering Committee for the Review of Government Service Provision, Report on Government Services 2020, Volume C: Justice (Commonwealth of Australia, 2020) Table 8A.13. 
may not have been part of the community in any real sense prior to their incarceration. ${ }^{78}$ For instance, family support has been found to be crucial for people to successfully stay out of prison after their release, but it has also been observed that 'this group is often marginalised upon release, with limited family and friend networks' ${ }^{79}$ It is also difficult when the socio-economic conditions people face upon release are similar to those they came from (as detailed in Chapter 1) — that is, characterised by poverty, unemployment and homelessness. ${ }^{80}$

Another possibility is that people may have been integrated into a particular subset of the community that supported the commission of crime prior to their imprisonment and returning to this subset will hinder law-abiding behaviour. These are what Cohen terms 'subcultures' that support and justify 'deviance' both before and after incarceration. ${ }^{81}$ This is not the broader community with which restorative prisons seek to connect imprisoned people.

\section{The Need for the Community to Support People Upon Their Return to Society}

Restorative prisons rely on the imprisoned person building relationships with the community so that the public improve their perception of imprisoned people, ready for their return after release. Detailed analysis of public perceptions in Australia is beyond the scope of this book. However, it may be noted that studies of the connection with 'reintegration' (defined as 'social inclusion, or productive membership of the community ${ }^{82}$ ) have found that the Australian community is generally not very supportive of people following their imprisonment and many members of the public express 'anxiety about personal interaction with ex-offenders'. ${ }^{83}$

78 Carlen argues that 'the bulk of those presently filling the prisons ... have never had anything to be rehabilitated to': Pat Carlen, 'Against Rehabilitation; For Reparative Justice' in Kerry Carrington et al (eds), Crime, Justice and Social Democracy: International Perspectives (Palgrave Macmillan, 2012) 102.

79 Alison Shinkfield and Joseph Graffam, 'Community Reintegration of Ex-Prisoners' (2009)

53(1) International Journal of Offender Therapy and Comparative Criminology 29, 30-1.

80 Carlen, above $\mathrm{n} 78,91$.

81 Stanley Cohen, Visions of Social Control: Crime, Punishment and Classification (Polity Press, 1985) 122.

82 Hardcastle, Bartholomew and Graffam, above n 17, 112-13.

83 Georgina Heydon and Bronwyn Naylor, 'Criminal Record Checking and Employment: The Importance of Policy and Proximity' (2018) 51(3) Australian \& New Zealand Journal of Criminology 372, 384 . 
A specific area where negative public perception is evident is employment, with an unwillingness on behalf of employers to 'hire ex-prisoners', as well as a structure in place-criminal record checks - that leads to stigmatisation. ${ }^{84}$ The importance of employment to connectedness with one's community has been noted by Heydon and Naylor as follows: '[f]ulfilling employment is clearly linked to reducing reoffending and increasing social participation of ex-offenders' ${ }^{85}$

\section{Linkages}

There is a clear connection between these barriers. People who are marginalised prior to their imprisonment face further marginalisation and stigmatisation following their imprisonment. Both of these hinder their ability to achieve connection with the community (a connection they may not have had prior to their incarceration). This is especially the case when the community may be hostile to their presence. Restorative justice initiatives aim to reduce this hostility, but its ability to do so when people are imprisoned a long way from the community where they normally reside, or within which they had problematic relations, is questionable. It is also difficult to overcome when there are legislative barriers to the employment of people with criminal records.

\section{Concluding Remarks}

Unfortunately, the balance of supporting arguments and barriers discussed here clearly favours the barriers. When writing about the possibility of restorative prisons in Australia, Goulding et al refer to it as requiring a 'radical transformation' ${ }^{86}$ The barriers exist because of the vast difference between restorative prisons and Australian prisons as they currently operate.

This does not affect the claim here that restorative prisons would be an appropriate way to achieve compliance with art 10(3) of the ICCPR. Moreover, it is certainly possible that some restorative justice processes could be implemented more widely in prisons, given that they are already present in some programs. This remains true even if it is very unlikely

84 Hardcastle, Bartholomew and Graffam, above n 17, 128. In relation to criminal record checks see Heydon and Naylor, above n 83, 373.

85 Heydon and Naylor, above n 83, 373.

86 Goulding, Hall and Steels, above $\mathrm{n} 70,240$. This is similar to the observations made about justice reinvestment that is being trialled in some communities around Australia, as detailed in Chapter 4. 
that all Australian jurisdictions will change their legislation to prioritise rehabilitation as required by international human rights law. This may help to tilt the balance back, even if only a little, against the weight of the barriers.

\section{Summary and Conclusion}

The goals of rehabilitation and social reformation are a prerequisite for human rights compliance in Australian prisons because of the requirement in art 10(3) of the ICCPR. This chapter outlined three problems that needed to be addressed if compliance with art 10(3) is to be achieved in Australian prisons. The first of these was that there is inadequate guidance issued by the HR Committee about how rehabilitation is to be achieved in practice. This problem has been addressed by reference to 'restorative prisons' which provide practical processes for achieving rehabilitation.

The second was that a detailed analysis of corrections and sentencing legislation reveals that rehabilitation does not feature as a goal in all Australian jurisdictions. In the jurisdictions where it does feature, it is one goal among many. Moreover, it is a goal that is not given prominence compared to other goals that, in the current punitive political climate, are considered to be more important. The emphasis on security in corrections legislation also precludes emphasis on rehabilitation. This may change if states and territories amend their legislation to comply with the second prerequisite (domestic legislative reform), particularly as a result of Australia's ratification of the OPCAT. Regardless of if or when this occurs, the practical processes offered in this chapter mean that rehabilitation could be pursued, even if it does not become the explicit and overarching goal of the prison system.

The third was that art 10(3) was drafted in an era when rehabilitation was given primacy in the way that it is not currently. This can be overcome by the rights-based model that aims to shifts the focus of rehabilitation to learning new skills, rather than involving 'treatment'. This is a more modern conceptualisation of rehabilitation. Within the rights-based model, rehabilitation can be 'restorative'. Although the GLM would be a possible strategy for implementing a restorative conception of rehabilitation in relation to therapeutic interventions, restorative justicebased approaches are preferred because of their broader application. 
In addition to assisting in the achievement of compliance with art 10(3) of the ICCPR, a restorative justice approach to rights-based rehabilitation is also consistent with other prerequisites for human rights compliance in prisons proposed in this book. Under this model, prison should remain a 'last resort' in accordance with the first prerequisite (Chapter 4), and staff have a duty to treat imprisoned people consistently with human rights in accordance with the fifth prerequisite (Chapter 7).

Significant barriers to compliance with this prerequisite in Australian prisons have been identified. These remain, despite the effort taken to identify an approach that overcomes the three major problems with it. This is where the advantages of restorative prisons may play a role. Quite apart from the contribution this model makes to achieving compliance with art 10(3), the processes may have appeal to victims, giving them a role that they do not currently have in the criminal justice system, and to the community more broadly. Restorative justice is also a wellestablished process in Australia, which may contribute to acceptance of its expansion into the penal domain. Changes of this nature are clearly required, given that rehabilitation as one of the goals of the Australian prison system is being overshadowed by other, counterproductive goals, precluding compliance with art 10(3) and other international human rights law requirements. 
This text is taken from Towards Human Rights Compliance in Australian Prisons, by Anita Mackay, published 2020 by ANU Press, The Australian National University, Canberra, Australia.

doi.org/10.22459/THRCAP.2020.06 